\title{
Trade Unions and Politics
}




\title{
Trade Unions and Politics
}

\author{
A comparative introduction
}

\author{
Andrew J. Taylor
}

Macmillan Education 
(C) Andrew Taylor 1989

ISBN 978-0-333-44946-2 ISBN 978-1-349-20135-8 (eBook)

DOI 10.1007/978-1-349-20135-8

Softcover reprint of the hardcover 1st edition 1989

All rights reserved. For information, write:

Scholarly and Reference Division,

St. Martin's Press, Inc., 175 Fifth Avenue, New York, NY 10010

First published in the United States of America in 1989

Library of Congress Cataloging-in-Publication Data

Taylor, Andrew, 1954-

Trade unions and politics : a cooperative introduction ; Andrew J. Taylor.

p. $\mathrm{cm}$.

Bibliography: $p$.

Includes index.

ISBN 978-0-312-03172-5

1. Trade-unions - Political activity. I. Title.

HD8031.T39 1989

$322^{\prime} .2-\mathrm{dc} 19$

89-5930

CIP 
For Helena Jayne 


\section{Contents}

List of Figures and Tables $\quad$ x

$\begin{array}{ll}\text { Preface } & \text { xiii }\end{array}$

Acknowledgements $\quad$ xvii

List of Abbreviations and Acronyms xix

1 Historical Background and Political Development 1

The inevitability of politics 1

The political development of British trade unions 3

The political development of American unions 5

The political development of Swedish unions 9

The political development of German unions 11

The political development of Japanese unions 14

$\begin{array}{ll}\text { Conclusions } & 17\end{array}$

2 Structure, Politics and Ideology 13

Trade union structure and political influence 19

Union government, oligarchy and political behaviour 22

Representational politics $\quad 30$

Union ideology and political behaviour $\quad 35$

Centralisation, fragmentation and political influence: conclusions 
The party-union relationship

The structural and organisational relationship $\quad 49$

Trade unions and party policy-making 58

$\begin{array}{ll}\text { Parties and unions: a Procrustean relationship } & 70\end{array}$

4 The Decline of Working Class Politics?

Recruitment and voting: decline or change?

Trade unions and the politics of recruitment

Trade unions and voting behaviour

81

Party politics: a poisoned chalice

The union-government relationship $\quad 96$

The evolution of the union-government relationship $\quad 98$

Trade union participation in policy-making 104

Integration in the Policy Process 105

The inclusion of unions in the policy process 107

The marginalisation of unions in the policy process 112

Corporatism and the politicisation of industrial relations 117

$\begin{array}{ll}\text { Conclusions } & 130\end{array}$

6 The Politics of the New Working Class 135

$\begin{array}{ll}\text { The white-collar phenomenon } & 135\end{array}$

Public sector trade unionism 142

Managing the unions in the 1990s 153

$\begin{array}{ll}\text { Conclusions } & 167\end{array}$

7 Unions, Power and Politics 172

$\begin{array}{ll}\text { Analytical perspectives } & 172\end{array}$

Definitions and strategies 176

Methods of trade union political action $\quad 179$

Unions, politics and capitalism 183

Unions and the problem of power 188

Unions, politics and the future 194 
Recommended Reading

Notes and References

204

Index

223 


\section{List of Figures and Tables}

Figure

2.1 Centralisation, fragmentation and political influence 18

Tables

2.1 Political influence, ranking by characteristics

3.1 TUC-Labour Party membership of ten largest party affiliated unions, 1986

4.1 Trade union representatives in the Bundestag, 1983-6 73

4.2 Bundestag members by DGB union affiliation, 1983-6

4.3 Union sponsored MPs in the Parliamentary Labour Party, 1983

4.4 Labour candidates and deputies elected to the Lower House of the Japanese Diet, 1980

4.5 Party preferences by socioeconomic group, \% of party electorate, Swedish general election, 1985

4.6 Trade union electorate, United Kingdom, 1974-87

4.7 Working class electoral behaviour, United States, 1952-84

4.8 Top ten money spending labour PACS, United States, 1983-4

4.9 Social network involvement by occupational category in the Japanese electorate

4.10 Voting by occupation and union category in the Japanese electorate 
6.1 Economically active population, \% employment by Industry, 1986 136

6.2 Sectoral employment, \% of civilian employment, 1960-84

6.3 Employment in government, \% of civilian employment, 1960-84 


\section{Preface}

The purpose of this book is to analyse and compare the role of trade unions as political actors in liberal-democratic industrial states: in particular, the United States, Britain, West Germany, Sweden and Japan. As such, it is not concerned with formal political institutions (for example, parties, parliaments, executives) so it assumes the reader will have some familiarity with the political institutions of the societies examined, although institutional detail has been included where necessary.

The comparative method has both advantages and disadvantages. The obvious advantage is breadth of study, which permits generalisations across political systems, enabling us to examine how the same phenomenon is treated in different political systems and contexts; this approach, however, sacrifices the detail of the specialised study. My experience of teaching comparative government and politics has caused me to be profoundly sceptical about its scientific possibilities and suspicious of grand theoretical frameworks - which often obscure more than they explain, and sometimes become an end in themselves - but the study of politics is essentially comparative. I have, therefore, striven to avoid presenting a potted country-by-country study in favour of a thematic approach, though most chapters analyse their subject matter according to country. Such a structure, though complex, allows the reader to follow the unions' political role in a particular system, or to pursue a theme across national boundaries. Only the reader can judge if the book achieves this.

Why write a comparative book on trade unions? The first reason is that comparative politics has in recent years shifted away from 
systemic comparison to sub-system comparison; virtually every political institution has been analysed comparatively but unions remain relatively understudied. There is a vast amount of material on individual states but few attempts to pull this material together in a digestible and convenient form. The second reason is that during the last decade or so unions have enjoyed a very bad press, being blamed for virtually every economic and political ill afflicting the industrial body politic. This might have made for good journalistic copy or political sloganeering but it is poor analysis. Unions are not perfect but they are certainly not the fount of all evil, they are the product of the society in which they are situated, and this book tries to place them in their context.

The central arguments of this book are that unions are inevitably political, whether they or politicians like it; that within capitalist industrial states they are relatively powerless; and that unions are primarily reactive and defensive in their political behaviour. As the international post-war economic boom collapsed in the 1970s unions were increasingly seen, to a greater or lesser degree, as a 'problem' about which something 'had to be done'. The purpose of this book is not to apportion blame or responsibility but to show how unions fit into the politics of liberal-democratic capitalism, and what their position is in the structure of political power. Authors, I believe, should always make their biases clear at the very outset; these are mine: unions meet a deep-seated need for collective protection from the operation of the market and, despite their faults and imperfections, unions remain a bulwark of democratic freedoms. No dictatorship of left or right can tolerate free, independent trade unions.

The central concern of comparative politics is the state. This book draws on the experience of five: the United Kingdom, the United States, the Federal Republic of Germany, Sweden and Japan. These five were selected because they represent a sample amenable to comparative analysis and represent a variety of liberal-democratic industrial political systems. The United Kingdom was chosen because of the long history of union political activism in the first industrial state, and because the UK is so often cited as an example of the consequences of excessive trade union power. The United States offers an opportunity to examine unions in a political culture hostile to collective action, but whose fragmented political system enables a well-organised group to achieve 
political influence. Sweden is interesting because of the ideological and political dominance of Social Democracy in which the unions are allocated a defined position within a corporatist political system. West Germany represents a case mid-way between the USA, the UK and Sweden. Here, an established union movement with a long history of political activism was destroyed and remade and accorded a legitimate role as a social partner in the increasingly conservative new German political system. Finally, Japan. In some ways Japan represents an obvious contrast to the other systems, but in other ways it exemplifies the subordination common to unions in the politics of the advanced capitalist industrial states. There is also considerable ignorance and misunderstanding about Japanese trade unions and industrial relations in the West; perhaps this book will enhance understanding of this complex, perplexing, yet fascinating, political system.

The organisation of the book is straightforward. It is a truism that the present is an extension of the past so Chapter 1 presents a brief overview of the political development of the five union movements in the twentieth century. This is examined through their growth as pressure groups, as electoral actors, and the evolution of their relationship with the state. Each of these is treated in greater detail in subsequent chapters. Chapter 2 explores the relationship between structure, ideology and political behaviour. It presents basic data on composition and the degree of centralisation in each union movement. The distribution of power in the unions, the nature of union government and internal union politics are considered as external behaviour is, in part, produced by internal politics. This leads to a discussion of the role of national union centres as labour's political spokesgroup. Finally, Chapter 2 examines the impact of voluntarism on union political behaviour and attitudes. Chapter 3 examines the party-union relationship. In particular, why unions attach themselves to a party, the variety of structural, ideological and personal connections and the role played by unions in making party policy. Chapter 4 continues the party-political theme through, first, the unions' role in recruiting the parliamentary elite and the degree of influence enjoyed by the unions over 'their' parliamentary representatives. This is then widened into an analysis of the voting behaviour of trade union members and, in particular, the impact of partisan dealignment. Chapter 5 considers the unions as interest 
groups, using variations of corporatism to analyse the different degrees of closeness enjoyed by union movements with their respective states. Chapter 5 concludes by analysing the breakdown of union-government relations in the 1970s. Chapter 6 is concerned with the rise of white-collar trade unionism, public sector trade unionism and the political management of the unions in the 1990s. Chapter 6 critically examines the 'new working class's' supposed consequences for 'traditional' unions as political actors: just how 'different' is the new working class? These chapters are the heart of the book and are concerned essentially with the politics of the 1970s and 1980s. Chapter 7 presents the book's conclusions and offers an analysis of the position of trade unions in the power structure of liberal capitalist industrial states, concluding that the image of union power cultivated in the media and by politicians has disguised their basic powerlessness.

In the late 1960s and 1970s unions were the target of polemics and a convenient scapegoat for the economic problems of the advanced capitalist economies caused by the destabilisation of the international economic balance created in the 1940s. Subsequent developments and continued economic instability have demonstrated that unions had little responsibility for events; though they are still universally regarded as a problem, it is now possible to begin a reassessment of their role in the political economy. This book is intended to be one small contribution to that process. 


\section{Acknowledgements}

This has been the most difficult book I have ever written, but this has not detracted from my enjoyment of the task. The difficulties have been eased and the enjoyment enhanced by my colleagues at Huddersfield. The research was excellently supported by the Library Staff at Huddersfield Polytechnic and help was provided by the Centre for Japanese Studies library (University of Sheffield). The London Embassies of the United States, Sweden, Japan and the Federal Republic of Germany provided much useful information from their own resources or were able to suggest individuals and organisations to contact, as did the TUC. It would take too long to thank the many individual trade unions in Britain, the USA, Sweden, West Germany and Japan who replied to my requests for information, but without their help the book would have been significantly poorer. Professor Watanuki (Sophia University) provided much useful information on Japanese unions. Steven Kennedy of Macmillan was a patient and encouraging editor. This book draws on my experience teaching my course, 'The Politics of the Advanced Industrial States', and I should like to acknowledge the contribution of my students at Huddersfield who have taken the course since its inception in 1981. I should also like to express my gratitude to my father who over the years has punctured my neat theories about unions and politics.

The author and publishers would like to acknowledge with thanks the International Labour Office for permission to reproduce extracts from The Yearbook of Labour Statistics 1986. Copyright (C) 1986, International Labour Organisation, Geneva.

Every effort has been made to trace all the copyright-holders, 
xviii Acknowledgements

but if any have been inadvertently overlooked the publishers will be pleased to make the necessary arrangement at the first opportunity.

Finally, my wife Dawn helped in the writing of this book in many more ways than she knows.

ANDREW J. TAYLOR 


\section{List of Abbreviations and Acronyms}

$\mathrm{ABF}$

ACAS

ADB

ADGB

AEU

AfA

AFGE

AFL

AFSCME

AFT

AMP

AMS

APEX

ASTMS
Workers' Educational Association

(Sweden)

Advisory, Conciliation and Arbritation

Service (UK)

General Federation of Civil Servants

(FRG)

General German Confederation of Trade Unions

Amalgamated Engineering Union

General Federation of Free Employees (FRG)

American Federation of Government

Employees

American Federation of Labor

American Federation of State, County

and Municipal Employees

American Federation of Teachers

Associate Membership Program (US)

National Labour Market Board

(Sweden)

Professional Executive and Computer Staff (UK)

Association of Scientific, Technical and Managerial Staffs (UK)

xix 
xx List of Abbreviations and Acronyms

BDA

BDI

CBI

CDU

CGD

Churitsuroren

CIO

CLP

CND

COHSE

COPE

COWPS

CPSA

CSU

CWA

DAG

DBB

DGB

DNC

Domei

DSP

ETU, now

EETPU

FDP

FOS

FPD

FRG

GCE
Federation of German Employers'

Associations

Federation of German Industry

Confederation of British Industry

Christian Democratic Union (FRG)

Christian Trade Union Federation

(FRG)

Federation of Independent Unions of Japan

Committee (now Congress) of Industrial

Organisations (US)

Constituency Labour Party

Council for National Defense (US)

Confederation of Health Service

Employees (UK)

Committee on Political Education (US)

Committee on Wages and Prices (US)

Civil and Public Servants' Association

Civil Service Union (UK)

Communication Workers of America

Salaried Employees' Union (FRG)

Civil Service Federation (FRG)

German Workers' Federation

Democratic National Committee (US)

Japan Confederation of Labour

Democratic Socialist Party (Japan)

Electrical Trades Union

Free Democratic Party

Modified Labour Market Model of Spring 1987 (Sweden)

Federal Postal Division (US)

Federal Republic of West Germany

Federation of Christian Trade Unions

(FRG) 
GCHQ

GDBG

GDP

GEDAG

GMBATU

HSC

ISTC

JSP

Keidanren

Koenkai

Komeito

Komuin Kyoto

Korokon

Korokyo

LAC

LDP

LKAB

LLPE

LMSA

LO

LPSL

LRC

MSC
Government Communications

Headquarters

Federation of German Civil Servants

Gross Domestic Product

Federation of German Salaried Staffs

General Municipal and Boilermakers

Allied Trade Unions

Health and Safety Commission (UK)

Steelworkers (UK)

Japan Socialist Party

Federation of Economic Organisations (Japan)

Personal support organisations (Japan)

Clean Government Party (Japan)

Joint Struggle Council of Government

Workers' Unions (Japan)

Roundtable Conference for Public

Corporations and National Enterprises

Labour Problems (Japan)

Council of Public Corporation and

National Enterprise Workers' Unions

(Japan)

Labor Advisory Council (US)

Liberal Democratic Party (Japan)

State mining corporation (Sweden)

Labor's League for Political Education (UK)

Labor-Management Services

Administration (US)

Landorganisationen i Sverige, Swedish

Trade Union Confederation

Local Public Service Law (Japan)

Labour Representation Committee (UK)

Manpower Services Commission (UK) 
MITI

NAGE

NALC

NALGO

NAM

NATGA

NEA

NEC

NEDC

NFFE

NGA

NHS

Nikkeiren

NIRA

NLRA

NLRB

NPA

NPSL

NTEU

NUM

NUPE

NUR

NUT

NUS

NWLB

OECD

OTV
Ministry of International Trade and Industry (Japan)

National Association of Government Employees (US)

National Association of Letter Carriers (US)

National Association of Local

Government Officers (UK)

National Association of Manufacturers (US)

National Air Traffic Controllers'

Association (US)

National Education Association (US)

National Executive Committee, of the

Labour Party (UK)

National Economic Development Council (UK)

National Federation of Federal

Employees (US)

National Graphical Association (UK)

National Health Service (UK)

Federation of Employers' Associations (Japan)

National Industry Recovery Act (US)

National Labor Relations Act (US)

National Labor Relations Board (US)

National Personnel Authority (Japan)

National Public Service Law (Japan)

National Treasury Employees' Union

(US)

National Union of Mineworkers (UK)

National Union of Public Employees (UK)

National Union of Railwaymen (UK)

National Union of Teachers (UK)

National Union of Seamen (UK)

National War Labor Board (US)

Organisation for Economic Cooperation and Development

Public Service and Transport Union (FRG) 
PAC

PATCO

PC

PCNELR

PCNELRC

PED

PLP

RCN

Rengo

SACO

SACO-SR

SAF

Sanbetsu-Kaigi

Sanrokon

SAP

SCAP

SCPS

SDP

Shinsanbetsu

Shunto

SLD

Sodomei

SOGAT 82

Sohyo
Political Action Committee (US)

Professional Air Traffic Controllers'

Association (US)

Personnel Commission (Japan)

Public Corporation and National

Enterprise Labour Relations Law

(Japan)

Public Corporation and National

Enterprises Labour Relations

Commission (Japan)

Public Employees' Division (US)

Parliamentary Labour Party (UK)

Royal College of Nurses

Confederation of Public Sector Trade

Unions (Japan)

Sveriges Akademikers

Centralorganisationen (Sweden)

SACO after its merger with the Civil

Service Federation (Sweden)

Svenska Arbetsforeningen, Swedish

Employers' Federation

Congress of Industrial Labour

Organisations (Japan)

Industry and Labour Roundtable

Conference (Japan)

Svenska Arbeter Partei, Social

Democratic Party (Sweden)

Supreme Command Allied Powers (Japan)

Society of Civil and Public Servants (UK)

Social Democratic Party (FRG)

National Federation of Industrial

Organisations

Spring Labor Offensive (Japan)

State/Local Division (US)

Japan Labour Federation

Society of Graphical and Allied Trades (19) 82

General Council of Trade Unions of

Japan 
xxiv List of Abbreviations and Acronyms

TASS

TCO

TGWU

TUC

TUCC

TUFL

TULV, now

TUFL

UAW

UCW

UK

UMWA

UPBP

US

USDAW

WCL

Zenmin Rokyo

Zenro (later

Domei)
Technical and Supervisory Staffs (UK)

Tjanstemannens centralorganisationen, Central organisation of salaried workers (Sweden)

Transport and General Workers' Union (UK)

Trades Union Congress (UK)

Trade Union Coordinating Committee (UK)

Trade Unions for Labour

Trade Unions for a Labour Victory (UK)

United Auto Workers

Union of Communication Workers (UK)

United Kingdom

United Mineworkers of America

Union Privilege Benefit Programs (US)

United States

Union of Shop, Distributive and Allied

Workers

War Committee of Labor (US)

Japan Private Sector Trade Union

Council

Japan Confederation of Labour 